\title{
DIVERSITY OF PLANT PARASITIC NEMATODES ASSOCIATED WITH RHIZOSPHERE OF MAIZE FROM DIFFERENT AREAS OF DISTRICT RAJOURI, JAMMU AND KASHMIR, INDIA
}

\author{
Kaisar Ahmad Allie ${ }^{1}$, Ali Asghar Shah ${ }^{2}$, Shaheen Majeed Wani' ${ }^{1}$, Kaisar Ahmad Bhat ${ }^{3}$, Nazia Kouser ${ }^{1}$, Rawhat- \\ un-Nisa ${ }^{1}$ \\ ${ }_{1}$ School of Biosciences and Biotechnology, Nematode Biodiversity Research Laboratory, Baba Ghulam Shah Badshah \\ University, Rajouri, Jammu and Kashmir, India. \\ ${ }^{2}$ Department of Zoology, Baba Ghulam Shah Badshah University, Rajouri, Jammu and Kashmir, India. \\ ${ }^{3}$ Division of Plant Biotechnology, Sheri Kashmir University of Agricultural Sciences and Technology, Jammu and Kashmir, \\ India.
}

ART I CLE IN F O

\section{Article history}

Received: 31st January, 2020

Revised: $19^{\text {th }}$ March, 2020

Accepted: 22 ${ }^{\text {nd }}$ March, 2020

Keywords

Maize

Nematode

Pratylenchus zeae

Diversity

\section{A B S T R A C T}

Diversity of plant parasitic nematodes in the rhizosphere of maize (Zea mays) from some areas of District Rajouri, Jammu and Kashmir was studied. A total of ten plant parasitic nematode species were found to be associated with the rhizosphere of maize plants in these areas. The nematode species were Pratylenchus zeae, $P$. brachyurus, Helicotylenchus dihystera, Longidorus brevicaudatus, L. elongatus, Xiphinema diversicadatum, X. elongatum, Tylenchorhynchus spp. Ditylenchus spp. and Criconemoides spp. The most dominant and frequently occurring species was found to be $P$. zeae, with absolute frequency of $86.66 \%$ followed by P. brachyurus (80\%), H. dihystera, (76.66\%) and L. brevicaudatus (73.33). Contrarily, the least frequent was Criconemoides spp. (36.66\%) followed by Tylenchorhynchus spp. and Ditylenchus spp. with absolute frequencies of $53.33 \%$ and $60 \%$. Similar trend was observed in case of relative frequencies. In case of $P$. zeae, mean density of 56 and relative density of $16.05 \%$ was observed followed by $P$. brachyurus and $H$. dihystera with mean densities and relative densities of 50.33, 14.43\% and 49, 14.04\% respectively. On the other hand, Criconemoides spp. and Tylenchorhynchus spp. showed mean densities of 6.33 and 23.33 and absolute densities of $1.81 \%$ and $6.68 \%$ respectively. P. zeae exhibited high prominence value of 57.85 followed by $P$. brachyurus (49.96). The least prominence value was found in Criconemoides spp. (4.05) followed by Tylenchorhynchus spp. with prominence value of 18.30 .

Corresponding Author: Kaisar Ahmad Allie

Email: kaisarf05@gmail.com

(C) 2020 EScience Press. All rights reserved.

\section{INTRODUCTION}

Maize (Zea mays L.) is a cereal grain and is the third most important cereal crop in the world as well as in India. It belongs to the grass family Poaceae. It was first grown by people in ancient Central America. In India, the crop covers an area of about 8.67 million hectares. Under the ISOPAM maize production programme, the production and productivity in India has increased to 
22.26 million tons and $2566 \mathrm{~kg} / \mathrm{ha}$ respectively during 2012-2013. Maize is cultivated in many parts of India like Karnataka, Maharashtra, Andhra Pradesh, Bihar etc. However, several factors limit the growth and production of maize which include both biotic and abiotic factors. Among the biotic factors, nematodes that feed on roots are one of the big stresses and limit the growth of maize and lead to heavy yield losses. The effects of parasitic nematodes on production of grain corn have been well studied (Norton, 1983, 1984; Windham, 1998). Although, several nematode species live in association within maize rhizosphere, maize cyst nematode (Heterodera zeae) is considered as one of the most important nematode pests of maize in India and abroad (Eisenback et al., 1993; Singh and Rathore, 2001). H. zeae was first reported by Koshy et al. (1970) from Chhapli village of Rajsamand district of Rajasthan. Walters (1979a, 1979b) published the first manuscript on nematodes associated with maize. The manuscript reports the extent of damage caused by plant parasitic nematodes on maize. The main factors that subject maize crops to nematode pests are low organic matter contents of soils and monoculturing of maize crop. Before 1995, Pratylenchus was generally perceived as the economically most important nematode pest genus that infected maize (De Waele and Jordaan, 1988; Jordaan et al., 1989; Louw, 1982; Walters, 1979a, 1979b; Zondagh and Van Rensburg, 1983). In India, Singh et al. (2007) reported various phytonematodes associated with maize viz. Heterodera, Pratylenchus, Tylenchorhynchus, Meloidogyne, Hoplolaimus, Helicotylenchus, Rotylenchus, Longidorus, Trichodorus, Xiphinema and Belonolaimus. According to Singh and Rathore (2001), H. zeae is known as the most important and frequently occurring nematode of maize crop. The annual yield losses of maize caused by this nematode is 17-29 \% in India (Srivastava and Chawla, 2005).

Plant parasitic nematodes heavily damage the crops and decrease the yield drastically. As maize is the staple food in Dhanore, Dhanidar, Kapakha, Chowdhary-naad, and Palma areas of District Rajouri, therefore, the aim of this work was to assess the diversity and occurrence of plant parasitic nematodes associated with the rhizosphere of maize from these areas.

\section{MATERIALS AND METHODS}

Survey and sample collection: A survey was conducted during May, 2019 for studying the diversity of nematodes associated with maize from different areas viz. Dhanore, Dhanidar, Kapakha, Chowdhary-naad, and Palma of District Rajouri (33.3717 $\mathrm{N}, 74.3153^{\circ} \mathrm{E}$ ), Jammu and Kashmir. About 30 samples were collected from rhizosphere of maize along with roots in air tight plastic bags. The collected samples were taken to the laboratory for sieving and isolation of nematodes.

Isolation of nematodes from soil: The samples were processed by Cobb's sieving and decanting method (Cobb, 1918) and Baermann funnel technique (Southey, 1986). The roots were cut into small pieces and then subjected to maceration with the help of mortar and pestle. The nematodes from the root paste were isolated by modified Baermann funnel technique (Hooper et al., 2005). After 12-24 hours, few water drops were taken from rubber tubing of Baermann funnel in a cavity block and observed under stereomicroscope. The nematodes were counted using Syracuse dish. For the identification of nematodes, temporary slides were made and studied under Olympus BX51 compound microscope.

Community analysis: For community analysis following parameters were calculated by using different formulae (Norton, 1978; Tomar et al., 2006).

Frequency

$=$ Number of samples in which the specimen was present

Absolute frequency

$$
=\frac{\text { Number of samples containing the specimen }}{\text { No. of samples collected }} \times 100
$$

Relative frequency

$$
\begin{aligned}
& =\frac{\text { Frequency of species }(\mathrm{N})}{\text { Sum of frequencies of all specimens present in samples }} \\
& \times 100 \\
& \text { Density } \\
& =\frac{\text { No. of specimens of given species counted in all samples }}{\text { No. of samples collected }} \\
& \times 100 \quad \begin{array}{r}
\text { Relative density } \\
=\frac{\text { Density of the specimen }}{\text { Sum of densities of all the nematode specimens }} \times 100 \\
\text { Prominence value of species } \\
=\text { Relative density } \\
\times \sqrt{\text { Relative frequency }}
\end{array}
\end{aligned}
$$

\section{RESULTS AND DISCUSSION}

Frequency of nematodes: A total of ten plant parasitic nematode species were found to be 
associated with the rhizosphere of maize fields in District Rajouri of Jammu and Kashmir. These identified species are Pratylenchus zeae, P. brachyurus, Helicotylenchus dihystera, Longidorus breviannulatus, L. elongatus Xiphinema diversicadatum, X. elongatum,
Tylenchorhynchus spp. Ditylenchus spp. Criconemoides spp. Among these, P. zeae was found to be the most abundant species followed by P. brachyurus. The least abundant species were Criconemoides spp. and Tylenchorhynchus spp. (Figure 1).

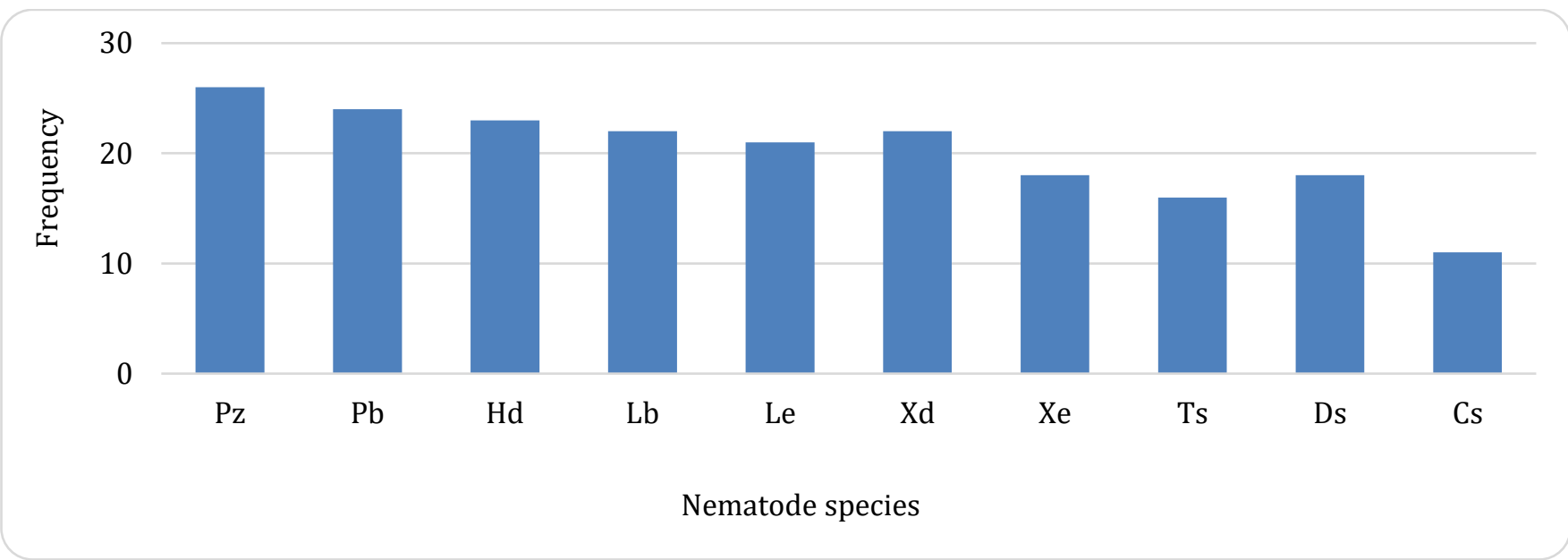

Figure 1. Frequencies of different nematode species in district Rajouri.

$\mathbf{P z}=$ Pratylenchus zeae, $\mathbf{P b}=$ P. brachyurus, $\mathbf{H d}=$ Helicotylenchus dihystera, $\mathbf{L b}=$ Longidorus brevicaudatus, $\mathbf{L e}=L$. elongatus, $\mathbf{X d}=$ Xiphinema diversicadatum, $\mathbf{X e}=$ X. elongatum, $\mathbf{T} \mathbf{s}=$ Tylenchorhynchus spp. $\mathbf{D s}=$ Ditylenchus spp. and Cs = Criconemoides spp.

Absolute and relative frequencies: The most dominant and frequently occurring species was found to be Pratylenchus zeae, with absolute frequency of $86.66 \%$. This was followed by P. brachyurus (80\%), Helicotylenchus dihystera, (76.66\%) and Longidorus brevicaudatus (73.33).
The least frequent was Criconemoides spp. (36.66\%) followed by Tylenchorhynchus spp. and Ditylenchus spp. with absolute frequencies of $53.33 \%$ and $60 \%$ (Figure 2). Similar trend was observed in case of relative frequencies as shown in figure 3 .

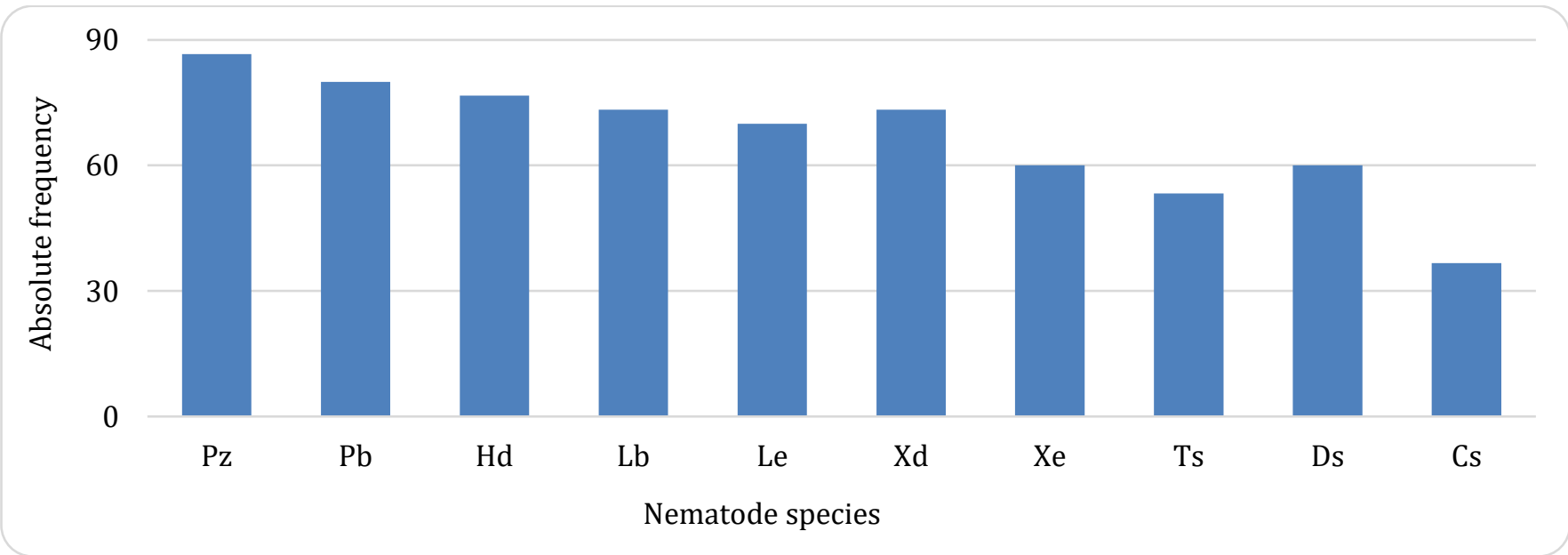

Figure 2. Absolute Frequencies of different nematode species in district Rajouri.

$\mathbf{P z}=$ Pratylenchus zeae, $\mathbf{P b}=$ P. brachyurus, $\mathbf{H d}=$ Helicotylenchus dihystera, $\mathbf{L b}=$ Longidorus brevicaudatus, $\mathbf{L e}=L$. elongatus, $\mathbf{X d}=$ Xiphinema diversicadatum, $\mathbf{X e}=$ X. elongatum, $\mathbf{T s}=$ Tylenchorhynchus spp. Ds = Ditylenchus spp. and Cs = Criconemoides spp. 


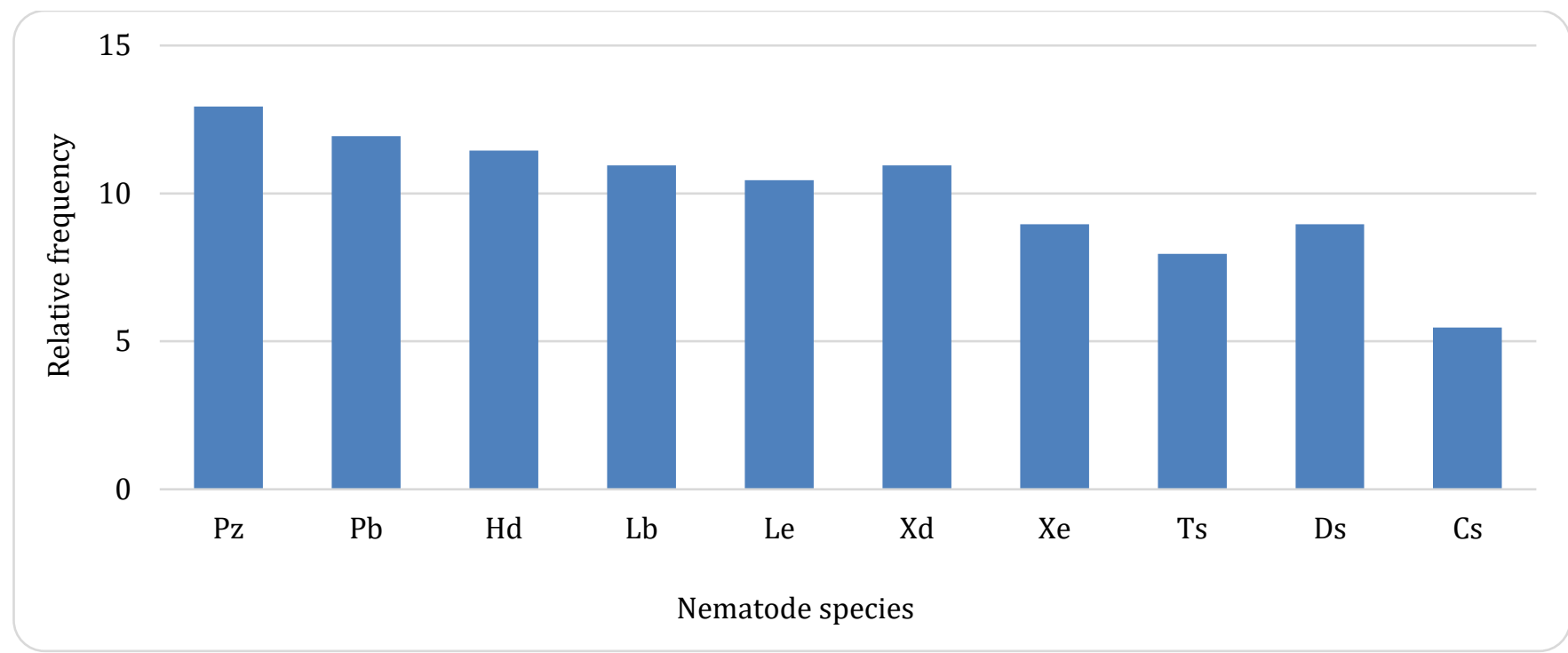

Figure 3. Relative frequencies of different nematode species in district Rajouri.

$\mathbf{P z}=$ Pratylenchus zeae, $\mathbf{P b}=$ P. brachyurus, $\mathbf{H d}=$ Helicotylenchus dihystera, $\mathbf{L b}=$ Longidorus brevicaudatus, $\mathbf{L e}=L$. elongatus, $\mathbf{X d}=$ Xiphinema diversicadatum, $\mathbf{X e}=$ X. elongatum, $\mathbf{T s}=$ Tylenchorhynchus spp. Ds = Ditylenchus spp. and Cs = Criconemoides spp.

Density and relative density: $P$. zeae, was the most dominant species with mean density of 56 and relative density of $16.5 \%$. This was followed by P. brachyurus and $H$. dihystera with mean densities and relative densities of $50.33,14.43 \%$ and $49,14.04 \%$ respectively. The least dominant was Criconemoides spp. and Tylenchorhynchus spp. with mean densities of 6.33 and
23.33 and absolute densities of $1.81 \%$ and $6.68 \%$ respectively (Figure 4 and 5).

Prominence value: $P$. zeae exhibited high prominence value of 57.85 followed by $P$. brachyurus (49.96). The least prominence value was found in Criconemoides (4.05) followed by Tylenchorhynchus spp. with prominence value of 18.30 (Figure 6).

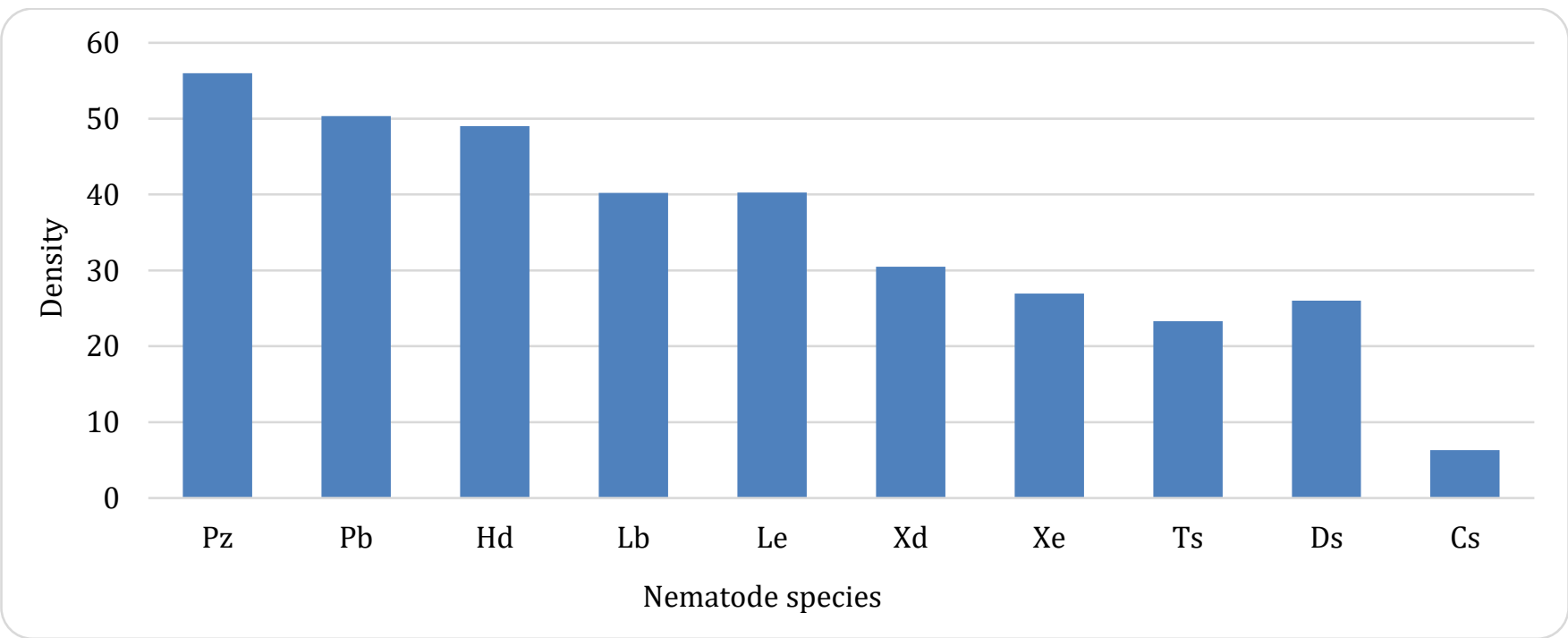

Figure 4. Densities of different nematode species in district Rajouri.

$\mathbf{P z}=$ Pratylenchus zeae, $\mathbf{P b}=$ P. brachyurus, $\mathbf{H d}=$ Helicotylenchus dihystera, $\mathbf{L} \mathbf{b}=$ Longidorus brevicaudatus, $\mathbf{L e}=L$. elongatus, $\mathbf{X d}=$ Xiphinema diversicadatum, $\mathbf{X e}=$ X. elongatum, $\mathbf{T s}=$ Tylenchorhynchus spp. Ds = Ditylenchus spp. and Cs = Criconemoides spp. 


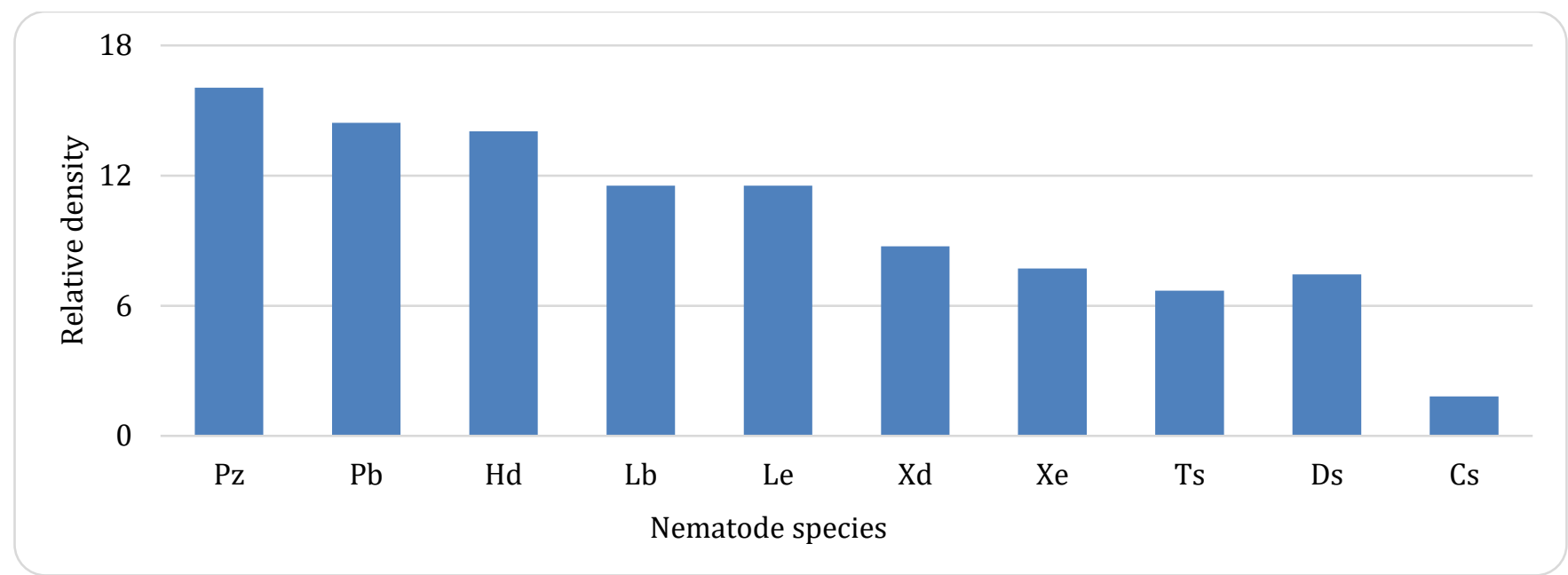

Figure 5. Relative densities of different nematode species in district Rajouri.

$\mathbf{P z}=$ Pratylenchus zeae, $\mathbf{P b}=$ P. brachyurus, $\mathbf{H d}=$ Helicotylenchus dihystera, $\mathbf{L b}=$ Longidorus brevicaudatus, $\mathbf{L e}=L$. elongatus, $\mathbf{X d}=$ Xiphinema diversicadatum, $\mathbf{X e}=$ X. elongatum, $\mathbf{T} \mathbf{s}=$ Tylenchorhynchus spp. $\mathbf{D s}=$ Ditylenchus spp. and Cs = Criconemoides spp.

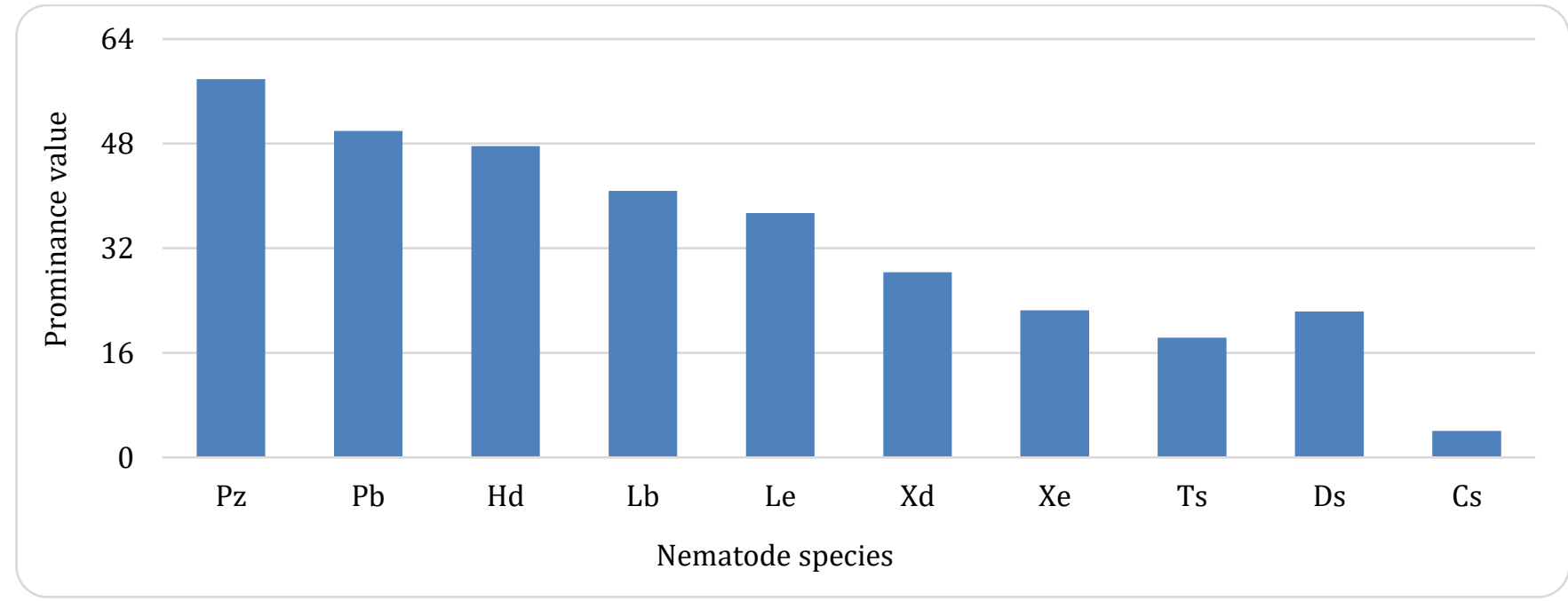

Figure 6. Prominence values of different nematode species in district Rajouri.

$\mathbf{P z}=$ Pratylenchus zeae, $\mathbf{P b}=$ P. brachyurus, $\mathbf{H d}=$ Helicotylenchus dihystera, $\mathbf{L b}=$ Longidorus brevicaudatus, $\mathbf{L e}=L$. elongatus, $\mathbf{X d}=$ Xiphinema diversicadatum, $\mathbf{X e}=$ X. elongatum, $\mathbf{T s}=$ Tylenchorhynchus spp. $\mathbf{D}$ s $=$ Ditylenchus spp. and Cs = Criconemoides spp.

The frequent occurrence of genera Helicotylenchus, Pratylenchus and Ditylenchus agrees with the observations of De Waele and Jordaan (1988), McDonald and Nicol (2005). The most abundant and dominant was $P$. zeae. According to De Waele and Jordaan (1988) and McDonald and Nicol (2005), in tropics P. zeae is a serious pest and one of the most common lesion nematode of maize. X. elongatum, Tylenchorhynchus spp. and Criconemoides spp. were less abundant and prevalent.
Being the most widespread and present in ample number, $P$. zeae is the major plant-parasitic nematode of maize in Dhanore, Dhanidar, Kapakha, Chowdhary- naad, and Palma areas of District Rajouri of Jammu and Kashmir.

\section{CONCLUSION}

From the above results, it is concluded that maize fields in Dhanore, Dhanidar, Kapakha, Chowdhary- naad, and Palma areas of District Rajouri of Jammu and Kashmir 
are heavily parasitized by phytophagous nematodes. Increase in nematode number, diversity and abundance is directly proportional to increase in crop loss and the crop yield will be heavily affected. To control these nematodes, the basic and the best management tool is crop rotation. The susceptible crop like maize should be followed by non-host crops. The application of synthetic nematicides like carbofuran is another way to limit the number of these nematodes in these areas.

\section{ACKNOWLEDGEMENT}

The authors are highly thankful to Department of Zoology for providing the necessary facilities.

\section{CONFLICT OF INTEREST}

The authors declare no conflict of interest.

\section{AUTHORS' CONTRIBUTION}

KAA, SMW and KAB designed and executed the study. $\mathrm{KAA}, \mathrm{KAB}, \mathrm{NK}$ and RUN analyzed the data and prepared the manuscript, AAS edited the manuscript. All the authors approved the final manuscript.

\section{REFERENCES}

Cobb, N.A., 1918. Estimating the nematode population of the soil. Agricultural Technology Circular 1, Bureau of Plant Industry. US Department of Agriculture, Batesville, 1-48.

De Waele, D., Jordaan, E.M., 1988. Plant-parasitic nematodes on field crops in South Africa. Revue de Nématologle 11, 65-74.

Eisenback, J.D., Reaver, D.M., Stromberg, E.L., 1993. First report of corn cyst nematode (Heterodera zeae) in Virginia. Plant Disease 77, 647.

Hooper, D.J., Hallmann, J., Subbotin, S.A., 2005. Methods for extraction, processing and detection of plant and soil nematodes.

Jordaan, E.M., De Waele, D., Van Rooyen, P.J., 1989. Endoparasitic nematodes in maize roots in the Western Transvaal as related to soil texture and rainfall. Journal of Nematology 21, 356.

Koshy, P., Swarup, G., Sethi, C., 1970. Heterodera zeae n. sp. (Nematoda: Heteroderidae) a cyst-forming nematode on Zea mays. Nematologica 16, 511-516.

Louw, I.W., 1982. Nematode pests of maize. Nematology in South Africa. Pretoria: Government Press, Science Bulletin, Department of Agriculture and Fisheries 400, 67-72.
McDonald, A.H., Nicol, J.M., 2005. Nematode Parasites of Cereals., in: M. Luc, R.A. Sikora, J. Bridge (Eds.), Plant Parasitic Nematodes in Subtropical and Tropical Agriculture. CAB International, pp. 131192.

Norton, D.C., 1978. Ecology of plant-parasitic nematodes. Wiley New York.

Norton, D.C., 1983. Maize nematode problems. Plant Disease 67, 253.

Norton, D.C., 1984. Nematodes parasites of corn, Plant and insect nematodes, pp. 61-95.

Singh, H., Rathore, B.S., 2001. Estimation of yield losses in maize due to maize cyst nematode, Heterodera zeae, National Congress on Centenary of Nematology in India-Appraisal and Future Plans held at IARI, New Delhi.

Singh, V.K., Kalia, C.S., Kaul, V., 2007. Occurrence of rootknot nematode, Meloidogyne incognita on maize in Jammu. Indian Journal of Nematology 37, 104-104.

Southey, J.F., 1986. Laboratory methods for work with plant and soil nematodes. HMSO, London.

Srivastava, A.N., Chawla, G., 2005. Maize cyst nematode, Heterodera zeae: A key nematode pest of maize and its management. Indian Agricultural Research Institute, Division of Nematology, New Delhi.

Tomar, V.V.S., Baniyamuddin, M.D., Ahmad, W., 2006. Community structure of soil inhabiting nematodes in a mango orchard at Aligarh, India. International Journal of Nematology 16, 89.

Walters, M.C., 1979a. Present status of knowledge of nematode damage and control in South Africa. Technical Communication No. 152. Department of Agricultural Technical Services, Pretoria, 62-68.

Walters, M.C., 1979b. The possible status of parasitic nematodes as limiting factors in maize production in South Africa. Technical Communication No. 142. Department of Agricultural Technical Services, Pretoria, 62-68.

Windham, G.L., 1998. Plant and nematode interactions. American Society of Agronomy.

Zondagh, S.G., Van Rensburg, J.B.J., 1983. Progress in nematode research in maize. Department of Agriculture and Fisheries, Pretoria, pp. 64-66. 